\title{
CHEMICZNA BIOLOGIA SYNTETYCZNA
}

\author{
CHEMICAL SYNTHETIC BIOLOGY
}

Ewa Huszcza

Katedra Chemii, Uniwersytet Przyrodniczy we Wrocławiu

ul. C. K. Norwida 25

50-375 Wroctaw

e-mail:ewa.huszcza@upwr.edu.pl

\author{
Abstract \\ Wykaz stosowanych skrótów \\ Wprowadzenie \\ 1. Założenia chemicznej biologii syntetycznej \\ 2. Kwasy ksenonukleinowe \\ 2.1. Modyfikacje części cukrowej \\ 2.2. Modyfikacje części zasady nukleinowej \\ 2.3. Modyfikacje części fosfodiestrowej \\ 2.4. Modyfikacje szkieletu nukleozydowego \\ 3. Rozszerzanie kodu genetycznego \\ 4. Ksenoenzymy \\ 5. Komórka minimalna \\ 5.1. Minimalny genom \\ 5.2. Syntetyczne bloki budulcowe \\ Uwagi końcowe \\ Podziękowania \\ Piśmiennictwo cytowane
}


Prof. dr hab. inż. Ewa Huszcza ukończyła studia na Wydziale Podstawowych Problemów Techniki Politechniki Wrocławskiej w 1990 roku na kierunku biotechnologia. Stopień doktora nauk chemicznych otrzymała w Instytucie Chemii Organicznej, Biochemii i Biotechnologii Politechniki Wrocławskiej w roku 1996 za pracę „Właściwości powierzchniowe lipopeptydów produkowanych przez bakterie Bacillus coagulans" wykonaną pod opieką prof. Bogdana Burczyka. Stopień doktora habilitowanego nauk biologicznych otrzymała na Wydziale Nauk o Żywności Uniwersytetu Przyrodniczego we Wrocławiu w 2009 roku. W 2014 roku otrzymała tytuł profesora nauk biologicznych. Pracuje na stanowisku profesora w Katedrze Chemii Uniwersytetu Przyrodniczego we Wrocławiu. Jej zainteresowania badawcze dotyczą otrzymywania biologicznie aktywnych związków na drodze biokatalizy. Najnowsze badania dotyczą otrzymywania metodami inżynierii genetycznej wydajnych modułów funkcjonalizujących flawonoidy.

https://orcid.org/0000-0002-5950-3695 


\begin{abstract}
Synthetic biology, which in 2020 turned 20 years old, is a very dynamically developing field. Unlike traditional molecular and cellular biology, synthetic biology focuses on the design and construction of parts, devices and systems such as enzymes, genetic circuits, metabolic pathways, etc. that can be modeled and adapted to specific requirements, and assembly into integrated systems for solving specific problems. The basic assumption of synthetic biology is the application of engineering principles such as standardization and modularity.

Synthetic biology is traditionally dominated by top-down approaches that incorporate or redesign well-characterized standard biological parts into cellular systems. In synthetic biology research there are also bottom-up approaches aiming to construct cell-like systems starting with molecular building blocks. This complementary approach is called "chemical synthetic biology." In this case the goal is to use unnatural chemicals to reproduce biological behavior. Under the bottom-up approach synthetic biology involves construction of so-called minimal cells or living cells from scratch and creating orthogonal biological systems based on biochemistry not found in nature. Bottom-up approaches complement the study of living cells, facilitate the definition of principles governing biological organization and identify new systems for biotechnological production.

Examples of breakthrough achievements in chemical synthetic biology such as peptide nucleic acids and selected developments over the past few years are presented in this review article.
\end{abstract}

Keywords: chemical synthetic biology, xenobiology, minimal cell

Słowa kluczowe: chemiczna biologia syntetyczna, ksenobiologia, komórka minimalna 


\section{WYKAZ STOSOWANYCH SKRÓTÓW}

BS

CBS

ncAA

XNA

XNAzym
- biologia syntetyczna

- chemiczna biologia syntetyczna

- niekanoniczny aminokwas

- kwas ksenonukleinowy

- ksenoenzym 


\section{WPROWADZENIE}

Biologia syntetyczna (BS) narodziła się na przełomie XX i XXI wieku, a jej rozwój znacząco przyspieszył szybki spadek kosztów i czasu gromadzenia danych z sekwencjonowania DNA, który nastąpił po zakończeniu Projektu Poznania Genomu Ludzkiego (Human Genome Project). BS opiera się na postępach w biologii molekularnej, komórkowej i biologii systemów. Rozwija biologię w taki sam sposób, w jaki synteza zmieniła chemię i jak projektowanie obwodów scalonych zmieniło informatykę. W odróżnieniu od tradycyjnej biologii molekularnej i komórkowej, biologia syntetyczna koncentruje się na projektowaniu i budowie części, takich jak DNA i enzymy i urządzeń, takich jak obwody genetyczne, szlaki metaboliczne itp., które można modelować i dostosowywać do określonych wymagań, a następnie tworzyć z nich większe zintegrowane systemy do rozwiązywania ściśle określonych problemów. Podobnie jak inżynierowie projektują układy scalone w oparciu o znane właściwości fizyczne materiałów, a następnie tworzą obwody i całe procesory, biolodzy syntetyczni projektują i konstruują układy biologiczne [1].

Ponieważ dziedzina BS leży na styku wielu różnych obszarów badań biologicznych, nie dla wszystkich badaczy oznacza to samo [2]. Ze względu na bezprecedensową multidyscyplinarność BS, w literaturze naukowej znaleźć można wiele jej definicji. Najczęściej powoływana opisuje BS jako projektowanie i tworzenie nowych biologicznych elementów syntetycznych, urządzeń i układów, jak również przeprojektowanie istniejących naturalnych układów biologicznych do użytecznych celów. Definicja ta wyraźnie odzwierciedla najpowszechniejsze, oparte na bioinżynierii podejście do BS, polegające na modyfikowaniu istniejących form życia drobnoustrojów i przekierowanie zawartości genomowej na nowe zmodyfikowane organizmy nie występujące w naturze. Podstawowym założeniem BS jest stosowanie zasad inżynieryjnych, takich jak standaryzacja i modułowość $[3,4]$.

Początek biologii syntetycznej datuje się na rok 2000, kiedy to zostały opublikowane dwie przełomowe dla tej dziedziny prace naukowe, opisujące konstrukcję części obwodów genetycznych takich jak syntetyczny oscylator [5] oraz genetyczny dwustabilny przełącznik [6]. W pierwszej dekadzie BS pojawiło się wiele publikacji opisujących otrzymywanie kolejnych syntetycznych obwodów biologicznych, jednak nie obserwowano postępów przy projektowaniu bardziej złożonych układów [7], aż do opracowania przez grupę Voigt'a kompleksowego systemu wspomagania komputerowego projektowania obwodów logicznych w bakteriach Escherichia coli [8]. Dzięki postępom w inżynierii metabolicznej, ukierunkowanej ewolucji (nagrodzonej Nagrodą Nobla w 2018 r.) [9], automatycznej inżynierii szczepów, odkrywaniu metagenomiki, projektowaniu 
obwodów genów i edycji genomu (nagrodzonej Nagrodą Nobla w 2020 r.) [10], wiele rozwiązań z zakresu BS zostało skomercjalizowanych [11, 12].

Obecnie liczba związków wytwarzanych z użyciem metod BS jest nadal dość ograniczona [13]. Bioprocesy o znaczeniu komercyjnym stanowią zaledwie kilka procent całkowitej ilości produkcji chemikaliów [14], mimo że nowatorskie produkty syntetycznej mikrobiologii są nie tylko pożądane, ale są oczywistą koniecznością W szybko zmieniającym się świecie, w którym dostęp do naturalnych, opartych na paliwach kopalnych zasobów staje się coraz bardziej ograniczony. Na skalę przemysłową otrzymywane są proste monomery stosowane do syntezy polimerów przemysłowych, takie jak: 1,3-propanodiol (DuPont) i 1,4butanodiol (Genomatica) [15] i inne proste cząsteczki, np. 5-cyjanopentanoamid (DuPont), kwas 5-metylopirazynowy (Lonza), $\beta$-karoten (BASF), izobutanol i farnezen (Gevo, Amyris) (Rys. 1) [16].

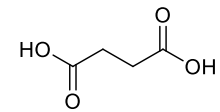

kwas bursztynowy

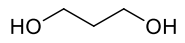

1,3-butanodiol<smiles>OCCCCO</smiles>

1,4-butanodiol<smiles>N#CCCCCC(N)=O</smiles>

5-cyjanopentanoamid

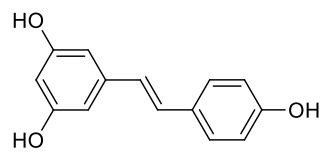

rezweratro<smiles>CSCCC[C@H](N)C(=O)O</smiles>

L-arginina$$
\text { L-metionina }
$$

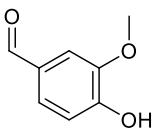

wanilina

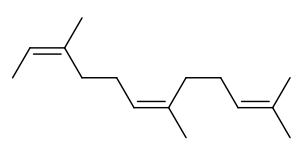

farnezen<smiles>Cc1cnc(C(=O)O)cn1</smiles>

kwas 5-metylopirazynowy

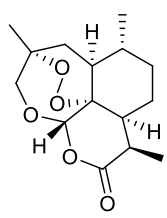

artemizynina

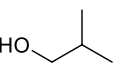

izobutanol

Rysunek 1. Wybrane produkty biologii syntetycznej otrzymywane przemysłowo

Figure 1. Representative synthetic biology products that have been commercialized

Przykładem znaczącego osiągnięcia BS jest stworzenie taniej metody przemysłowego otrzymywania artemizyniny, będącej składnikiem skutecznych leków przeciwmalarycznych. Artemizynina jest pozyskiwana $\mathrm{z}$ materiału roślinnego - bylicy rocznej (Artemisia апnua). Synteza chemiczna tego seskwiterpenowego laktonu o siedmiu centrach stereogenicznych i unikalnym pod względem stabilności mostku tlenowym (Rys. 1) obejmuje wiele etapów i nie może pod względem ekonomicznym konkurować z ekstrakcją z materiału roślinnego. 
Aby obniżyć koszt leków i uczynić je szerzej dostępnymi, wykorzystano BS do modyfikacji genetycznej drożdży by wytwarzały kwas artemizyninowy, który jest następnie przekształcany chemicznie do artemizyniny [17]. Przemysłową produkcję semisyntetycznej artemizyniny ze źródeł odnawialnych firma Sanofi rozpoczęła w 2013 roku.

Doskonałym przykładem aktualnych umiejętności biologów syntetycznych w zakresie projektowania organizmów mających zaspokajać pojawiające się potrzeby w medycynie, rolnictwie i przemyśle jest wynik eksperymentu, który na zlecenie amerykańskiej agencji rządowej zajmującej się rozwojem technologii wojskowej, działającej w strukturach Departamentu Obrony (Defense Advanced Research Projects Agency) wykonała grupa badaczy pochodzących z jednostek wiodących $\mathrm{w}$ tej dziedzinie [18]. Zadanie polegało na opracowaniu metod otrzymywania 10 związków, nad którymi uczestnicy projektu nigdy wcześniej nie pracowali, w trzy miesiące (liczone od poznania cząsteczek docelowych). Lista związków obejmowała proste chemikalia, które już wcześniej były produkowane przez organizmy rekombinowane (1-heksadekanol, pirolonitryna, rebekamycyna i pacydamycyna D), złożone produkty naturalne z roślin, których szlaki biosyntezy były znane, ale związki te nie były jeszcze wytwarzane rekombinacyjnie (karwon, barbamid i C-1027), takie których szlaki biosyntezy nie były jeszcze dobrze rozpoznane (epikolakton, winkrystyna) oraz związki nienaturalne (tetrahydrofuran) (Rys. 2).

Stosując różnorodne podejścia, w zadanym czasie stworzono pożądaną lub blisko spokrewnioną cząsteczkę dla sześciu z 10 celów. Zwiększono produkcję 1heksadekanolu, pirolonitryny i pacydamycyny $\mathrm{D}$, opracowano nową metodę otrzymywania aglikonu rebekamycyny, bloku budulcowego do otrzymywania C1027 (silnego środka przeciwdrobnoustrojowego) i winkrystyny oraz nowy bezkomórkowy system produkcji limonenu. Zaprojektowano i skonstruowano ścieżki do produkcji tetrahydrofuranu i barbamidu. Zadanie wiązało się z opracowaniem 215 szczepów drobnoustrojów obejmujących pięć gatunków i dwóch systemów bezkomórkowych [18]. 
<smiles>COCCO[C@@H](C)O[C@@H]1[C@@H](CO)O[C@@H](n2c3c(Cl)cccc3c3c4[nH]c5c(Cl)cccc5c4c4c(c32)C(=O)NC4=O)[C@H](O)[C@H]1O</smiles><smiles>CO/C(=C/C(=O)N(C)C(Cc1ccccc1)c1nccs1)CC(C)C(Cl)(Cl)Cl</smiles>
tetrahydrofuran

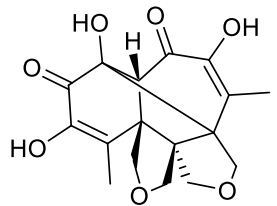

epikolakton<smiles>O=[N+]([O-])c1c(Cl)cccc1-c1c[nH]cc1Cl</smiles>

pirolonitryna

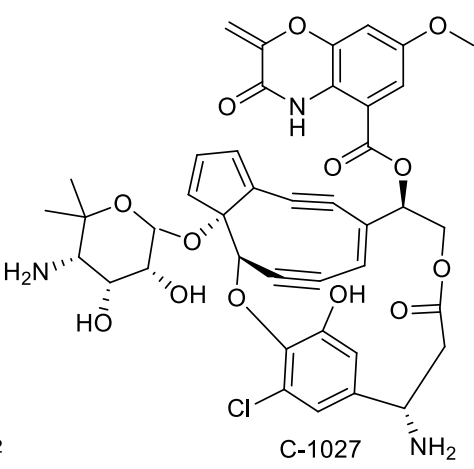<smiles>C/C=C\C=C/[C@]1(CC)C=CCN(C)C1</smiles>

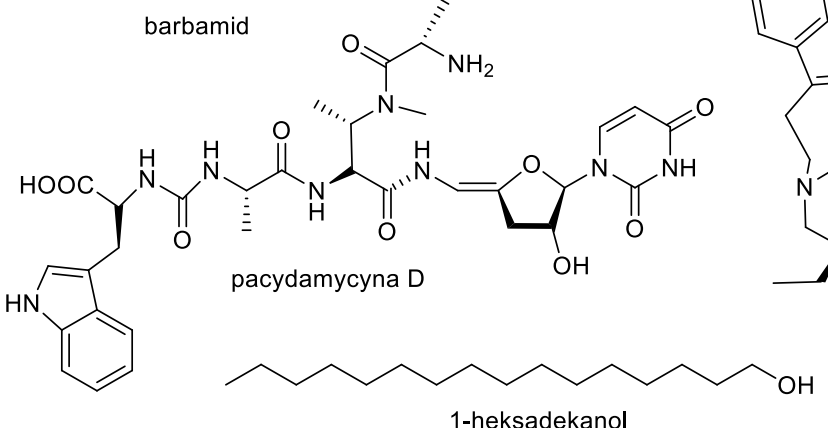<smiles>CCCCc1c(C2(C(=O)OC)CCCCC2)[nH]c2ccccc12</smiles>

winkrystyna<smiles>C=C(C)C1CC=C(C)C(=O)C1</smiles>

karwon

Rysunek 2. Cele zewnętrznej ewaluacji metod biologii syntetycznej „10 związków w 90 dni” [18]

Figure 2. Targets of external evaluation of synthetic biology methods "10 compounds in 90 days" [18]

\section{ZAŁOŻENIA CHEMICZNEJ BIOLOGII SYNTETYCZNEJ}

Biologia syntetyczna jest tradycyjnie zdominowana przez podejścia odgórne (top-down), które polegają na wprowadzeniu lub przeprojektowaniu dobrze scharakteryzowanych standardowych części biologicznych do systemów komórkowych, w celu uzyskania określonego efektu, co opisano we Wprowadzeniu. W ten sposób naturalne cząsteczki są używane do tworzenia sztucznych komórek, które pełnią nienaturalne funkcje. W badaniach z zakresu BS obserwuje się również podejścia oddolne (bottom-up), zmierzające do konstruowania systemów podobnych do komórek, zaczynając od molekularnych bloków budulcowych. To uzupełniające podejście jest charakterystyczne dla „chemicznej” gałęzi biologii syntetycznej, zwanej „chemiczną biologią syntetyczną". W tym przypadku celem jest użycie nienaturalnych związków chemicznych do odtworzenia zachowań biologicznych bez tworzenia dokładnej 
repliki molekularnej naturalnego układu żywego [19]. W ramach podejścia oddolnego BS obejmuje konstruowanie tzw. komórek minimalnych, czyli żywych komórek od podstaw oraz tworzenie ortogonalnych układów biologicznych $\mathrm{W}$ oparciu o biochemię niespotykaną $\mathrm{w}$ przyrodzie [20]. Podejścia oddolne uzupełniają badania nad żywymi komórkami, ułatwiają definiowanie zasad rządzących organizacją biologiczną i identyfikują nowe systemy produkcji biotechnologicznej [21].

Niniejszy artykuł poświęcony jest chemicznej biologii syntetycznej (CBS) poddziedzinie która nie opiera się na manipulacji genetycznej, natomiast kładzie nacisk na podejście chemiczne w celu syntezy, chemicznej lub biochemicznej, struktur molekularnych i wielocząsteczkowych zorganizowanych systemów biologicznych nie występujących $\mathrm{w}$ przyrodzie [22]. CBS jest określana alternatywnie terminem „ksenobiologia”, przy czym należy tu zaznaczyć, że w kontekście biologii syntetycznej ksenobiologia nie obejmuje poszukiwania życia pozaziemskiego [23]. U podstaw tego rodzaju badań leży pytanie czy droga natury jest jedyną obowiązującą ścieżką. Syntezując w laboratoriach alternatywne, nie występujące w naturze związki i porównując je z formami naturalnymi, badacze działający w obszarze CBS starają się wyjaśnić dlaczego życie ewoluowało tak a nie inaczej. Na przykład czy wybór rybozy jako składnika kwasów nukleinowych, czy też 20 aminokwasów do tworzenia białek to efekt determinizmu czy przypadku. CBS jest więc bardziej nastawiona na nauki podstawowe niż na podejście inżynierskie, zwykle poświęcone z góry określonemu celowi [22].

Opierając się na założeniu, że życie mogło ewoluować inaczej, naukowcy próbują projektować i tworzyć formy życia, a przynajmniej układy biologiczne, oparte na nienaturalnych strukturach biochemicznych. Ich wysiłki skupiają się na otrzymywaniu alternatywnych biomolekuł które mogłyby podtrzymywać procesy życiowe. Obszary badań na poziomie molekularnym obejmują między innymi chemiczną modyfikację DNA, polimeraz, aminokwasów, białek i tworzenie form pęcherzykowych. Bardziej wizjonerskie pomysły zakładają zastąpienie węgla krzemem w podstawowych biomolekułach lub tworzenie form życia, które nie tylko wykorzystują elementy nienaturalne, ale także architekturę całkowicie odmienną od naturalnej budowy genomu, rybosomu i białka [23]. Dodatkowym efektem takich działań może być wytworzenie wielu narzędzi opartych na nienaturalnych związkach do wykorzystania $\mathrm{w}$ nanomedycynie, diagnostyce, dostarczaniu leków/genów, bioinżynierii itp. 


\section{KWASY KSENONUKLEINOWE}

W ciągu ostatnich kilku dziesięcioleci zaprojektowano i zsyntetyzowano wiele zmodyfikowanych chemicznie kwasów nukleinowych, zwanych kwasami ksenonukleinowymi (XNA). Modyfikacje te dotyczyły zasad nukleinowych, cukrów, fosfodiestru lub ich kombinacji. W porównaniu z naturalnymi DNA i RNA - XNA mają podobne, często lepsze właściwości chemiczne i biologiczne, co sprawia, że są skuteczniejsze $\mathrm{W}$ zastosowaniach biomedycznych i biotechnologicznych. Nie wykazano jeszcze że XNA mogą zastąpić DNA i funkcjonować jako materiał genetyczny w żywych komórkach, jednak w naturze zidentyfikowano wiele odmian szkieletów zasad nukleinowych, cukrowych i fosforanowych DNA i RNA, co dowodzi, że możliwa jest integracja alternatywnych zestawów genetycznych z żywymi systemami [24]. Wstępne badania wykazały, że informacja genetyczna kodowana przez XNA wewnątrz plazmidu może być wykorzystana do generowania kopii DNA. Za pomocą polimeraz XNA wyewoluowanych $w$ laboratoriach, informacja genetyczna zakodowana w XNA może być przenoszona do i z DNA, co sugeruje, że niektóre XNA mogą funkcjonować jako alternatywny materiał genetyczny in vivo. Poprzez wstawienie nienaturalnych par zasad z powodzeniem konstruowano organizmy półsyntetyczne o rozszerzonych genomach [25]. Wszystkie te wyniki wskazują na możliwość wykorzystania alternatywnych XNA do tworzenia sztucznego życia.

Modyfikacja zasad nukleinowych może modulować siłę i specyficzność parowania zasad, a zmiany szkieletu fosfodiestrowego zwiększyć odporność na nukleazy i polepszyć właściwości farmakokinetyczne. Z kolei modyfikacje elementów cukrowych mają znaczący wpływ na różne właściwości, takie jak zdolność tworzenia dupleksu, odporność na nukleazy i toksyczność. Przy konstruowaniu nienaturalnych kwasów nukleinowych spełnione muszą być trzy kryteria projektowe: parowanie zasad, kompatybilność $\mathrm{z}$ naturalną lub modyfikowaną polimerazą DNA oraz kompatybilność z polimerazą RNA [26].

\subsection{MODYFIKACJE CZĘŚCI CUKROWEJ}

Chociaż każdy z trzech głównych elementów kwasu nukleinowego, tj. zasada nukleinowa, wiązanie fosfodiestrowego i ugrupowanie cukrowe, odgrywa ważną rolę we właściwościach strukturalnych i funkcjonalnych tego polimeru, to zdolność niektórych XNA do krzyżowania się z DNA i RNA zależy od ugrupowania cukrowego, ponieważ determinuje ono geometrię spiralną dupleksu [27]. Na przykład DNA faworyzuje helisę $\mathrm{w}$ formie $\mathrm{B} \mathrm{z}$ dezoksyrybozą o konformacji 2'-endo, podczas gdy RNA preferuje helisę $\mathrm{w}$ formie A z rybozą o konformacji 3'-endo. Zmiany konformacji spiralnej występują gdy naturalny cukier jest 
zastępowany innym rodzajem cukru. Na przykład kwas arabinonukleinowy (ANA), analog RNA, w którym grupa 2'-hydroksylowa skierowana jest ku górze, przyjmuje geometrię helikalną formy B zamiast standardowej geometrii formy A, powszechnie obserwowanej dla RNA (Rys. 3) [28]. Podobnie, gdy do dezoksyrybozy wprowadza się grupę 4'-tiolową (4'ThioDNA), odpowiedni analog DNA tworzy helisę w kształcie litery A, a nie standardową o geometrii formy $\mathrm{B}$, powszechnie obserwowaną dla DNA (Rys. 3) [29].
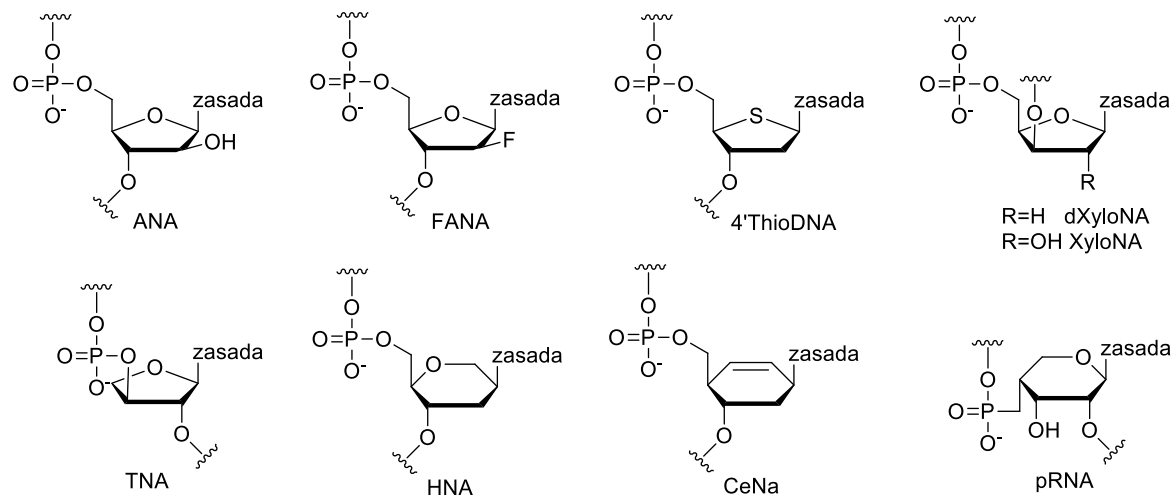

Rysunek 3. Kwasy ksenonukleinowe ze zmodyfikowaną częścią cukrową Figure 3. Sugar modified xenonucleic acids

W literaturze opisano wiele XNA, z których większość nie jest w stanie sparować się z DNA i RNA, ponieważ ich parametry strukturalne leżą poza przestrzenią konformacyjną określoną przez helisy w formie A i B [30, 31]. Jednak szczegółowo opisano dwa znaczące przypadki, w których krzyżowanie XNA z DNA i RNA występuje z wysoką wydajnością. Pierwszym z nich jest kwas treozonukleinowy (TNA), w którym naturalną pięciowęglową rybozę zastąpiono syntetyczną czterowęglową treozą [32] i anhydroheksytolem (HNA), pochodzącym od sześciowęglowej piranozy [33]. TNA i HNA mogą być zdolne do wymiany informacji genetycznej z polimerami kwasu nukleinowego innymi niż DNA i RNA, ponieważ wykazują oznaki niejednorodności strukturalnej w zależności od tego, czy są sparowane ze sobą, czy też z naturalnym polimerem genetycznym [34, 35]. W przypadku zidentyfikowania takich przypadków, TNA i HNA mogą służyć jako pomost, umożliwiając przepływ informacji z naturalnych kwasów nukleinowych do syntetycznych polimerów genetyczmychXNA, które nie są zdolne do parowania zasad z DNA i RNA.

Ortogonalnymi XNA są między innymi kwasy deoksyksylonukleinowy (dXylNA), ksylonukleinowy (XylNA) i piranozylonukleinowy (pNA), który jest kolejnym przykładem systemu samoparowania, który jest ortogonalny do DNA 
i RNA [36]. W przypadku ANA, HNA, kwasu 2'-fluoroarabinonukleinowego (FANA) i cykloheksenowego (CeNA) zaobserwowano, że mogą tworzyć w pełni syntetyczny układ katalityczny, który nazwano XNAzymem (Rys. 3) [37]. XNAzymy każdego z czterech wymienionych typów XNA mogą rozcinać wiązanie fosfodiestrowe w RNA, wykazując aktywność endonukleazy RNA działać jako ligazy RNA. XNAzymy katalizują tworzenie oligomerów XNA o długości do 100 nukleotydów. Otrzymane XNAzymy o aktywności ligazy są zdolne do katalizowania syntezy XNAzymów o aktywności endonukleazy RNA. Ostatnie badania wykazały, że dXylNA i XylNA tworzą struktury spinki do włosów stabilniejsze od dotychczas opisanych przykładów [38].

\subsection{MODYFIKACJE CZĘŚCI ZASADY NUKLEINOWEJ}

Idea wprowadzania syntetycznych związków heterocyklicznych zamiast natywnych zasad do DNA i RNA jest realizowana od prawie 60 lat. Nienaturalne zasady mogą rozszerzyć kod genetyczny i wprowadzić nowe funkcje makromolekularne, przez co badania tego typu są jednymi z podstawowych w biologii syntetycznej. Większość doniesień literaturowych dotyczy rozszerzania kodu, inne koncentrują się na dokowaniu syntetycznych heterocykli do niekodujących fragmentów kwasów nukleinowych. To drugie, rzadziej stosowane podejście, ma na celu wyjaśnienie głównych procesów z udziałem kwasów nukleinowych, w tym regulacji transkrypcji, translacji, transportu i czasu życia transkryptów.

Postęp w dziedzinie chemii związków heterocyklicznnych umożliwił skonstruowanie dużej liczby analogów zasad nukleinowych. Wprowadzania grup funkcyjnych do kwasów nukleinowych w tym miejscu zwykle powoduje tylko niewielkie zakłócenie w rozpoznawaniu typu Watsona-Cricka, a zatem nie zakłóca informacji genetycznej przenoszonej przez sekwencje DNA lub RNA [39, 40]. Jednocześnie zmodyfikowane zasady nukleinowe mogą zwiększać stabilność termiczną dupleksów i aktywność wyciszania genów [41-43], umożliwiają wprowadzenie znaczników fluorescencyjnych [44] lub redoks [45]. Przenoszą dodatkową reaktywność $[46,47]$ lub poszerzają alfabet genetyczny [48, 49].

Istnieją dwie podstawowe strategie $\mathrm{w}$ obszarze modyfikowania: pierwsza ma na celu utrzymanie podobnej do Watsona-Cricka sieci wiązań wodorowych między zasadami, podczas gdy druga strategia wykorzystuje grupy hydrofobowe, które naśladują kształt i polarność naturalnych zasad. W pierwszej z tych strategii rozwijano biologię syntetyczną opartą na sztucznie rozszerzonych systemach informacji genetycznej. Systemy te zawierają sześć lub więcej par zasad nukleotydowych, z których każda nadal jest zgodna $\mathrm{z}$ podstawową geometrią Watsona-Cricka, ale różni się układem donorów i akceptorów w wiązaniach 
wodorowych w syntetycznych parach zasad, przykładem mogą być pary izoC:izoG i Z:P (Rys. 4). Para zasad Z:P jest łatwo włączana przez polimerazy DNA, z 97,5\% zachowaniem nienaturalnej pary zasad podczas amplifikacji PCR [50], a ponadto $\alpha$-tiotrifosforan zawierający nukleozasadę $\mathrm{P}$ może być wykorzystany przez polimerazy do wytworzenia oligonukleotydu zawierającego tiofosforan [51]. Syntetyczny sześcioliterowy system genetyczny obejmujący „biocegiełki” G, A, C, T, Z i P (Rys. 4) nie jest homologiczny z systemem genetycznym który naturalnie znajdujemy na Ziemi, jednak ma wiele wspólnych cech strukturalnych $\mathrm{z}$ naturalnymi systemami genetycznymi [1].

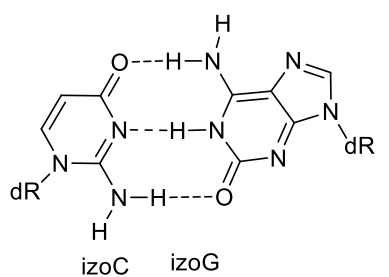

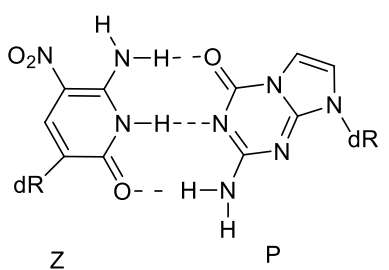<smiles>O=c1[nH]c(=O)n([Tl])c2ccccc12</smiles><smiles>Nc1ncnc2cc3c(cc12)ncn3-c1ccccc1</smiles>
$x A$<smiles>Cc1cc([Tl])cc2c(=O)nc(N)[nH]c12</smiles><smiles>[R7]c1cc(C)cc2c(=O)nc(NN)[nH]c12</smiles><smiles>CN(C)c1cccc(-c2cccs2)n1</smiles>

Ds<smiles>CCC#Cc1cc([N+](=O)[O-])n([Ga])c1</smiles>

Px<smiles>[R7]C1=CC=C2C=C(C)C=CC2C1=S</smiles>

5 SICS<smiles>[R]c1cc2ccccc2cc1OCC</smiles>

Rysunek 4. Kwasy ksenonukleinowe modyfikowane w części zasady nukleinowej

Figure 4. Base modified xenonucleic acids

Zasady nukleinowe o rozbudowanej strukturze xA, xC, yT i yC (Rys. 4) mogą być replikowane przez polimerazy w $E$. coli, ale tylko w przypadku xA i xC wierność replikacji jest wysoka [52].

Hydrofobowe podejście do opracowania syntetycznych par zasad ma na celu naśladowanie rozmiaru, kształtu i w niektórych przypadkach polaryzacji naturalnej pary zasad, ale nie wiązania wodorowego. Przykładami par zasad typu hydrofobowego mogą być Ds:Px i 5SICS:NaM (Rys. 4). Sekwencje z parą Ds:Px

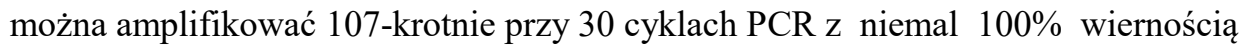


[53]. Para 5SICS:NaM może występować zarówno w nici sensownej, jak i antysensownej DNA bez utraty wydajności replikacji i translacji [54, 55]. Zastosowanie grupy propargilowej w nukleozasadach, np. w Px, dC ${ }^{\mathrm{ESQ}}$, umożliwia łatwe włączenie wielu grup funkcyjnych (Rys. 4) [56].

\subsection{MODYFIKACJE CZEŚCI FOSFODIESTROWEJ}

Szkielet fosforanowy łączący ze sobą nukleotydy w DNA i RNA jest w warunkach fizjologicznych obdarzony ładunkiem ujemnym, co stanowi dużą przeszkodę $\mathrm{W}$ przekraczaniu błon biologicznych. Ponadto endogenne egzoi endonukleazy hydrolizują wiązania fosfodiestrowe, degradując DNA i RNA w ciągu kilku minut. Wiele alternatyw dla wiązania fosfodiestrowego zostało przebadanych, głównie z zamiarem zwiększenia odporności na degradację prowadzoną przez nukleazy [57].

Często stosowanym analogiem fosfodiestrowym o zwiększonej hydrofobowości jest tiofosforan, w którym jeden atom tlenu grupy fosforanowej jest zastąpiony atomem siarki (Rys. 5). Wiele polimeraz DNA akceptuje trifosforanową wersję tej pochodnej, w której siarka występuje w pozycji $\alpha$ trifosforanu [58]. Wiązania tiofosforanowe są chiralne, posiadają centrum stereogeniczne przy atomie fosforu. Badania wykazały, że kilka polimeraz selektywnie wykorzystuje stereoizomer Sp zmodyfikowanego siarką trifosforanu nukleozydu i że polimeryzacja przebiega $\mathrm{z}$ odwróceniem konfiguracji na atomie fosforu [59-61]. Rybosomy akceptują mRNA z modyfikacją tiofosforanową [62], a niektóre bakterie naturalnie włączają tiofosforany do swoich genomów [63].<smiles></smiles><smiles>[13CH3]OP([13CH3])(=O)O[13CH3]</smiles><smiles></smiles><smiles>COCc1cn(C[Se])nn1</smiles>

Rysunek 5. Kwasy ksenonukleinowe modyfikowane w części fosfodiestrowej łącznikami fosforotionanforanowym, boranofosforanowyn, fosfonianowym i triazoliowym

Figure 5. Phosphodiester backbone modified xenonucleic acids by phosphorotioate, boranophosphate, phosphonate and triazole linkages

Analogi boranofosforanowe (Rys. 5) są podobnie jak tiofosforany tolerowane przez polimerazy i rybosomy [64]. Z kolei analogi fosfonianowe (Rys. 5), zawierające dodatkową grupę metylenową między atomem 5' tlenu a atomem 
fosforu, są wysoce odporne na degradację nukleazową [65]. Polimerazy preferują włączanie pochodnych fosfonianowych $\mathrm{z}$ adeniną i cytozyną, podczas gdy analogi $\mathrm{z}$ tyminą $\mathrm{i}$ uracylem są włączane $\mathrm{w}$ ograniczonym zakresie. Naturalny trifosforan nukleozydu adeninowego jest preferowany w porównaniu $\mathrm{z}$ wersją fosfonianową, co wymaga dalszych badań zarówno nad tymi związkami, jak i nad inżynierią polimeraz [66].

Jedna $\mathrm{z}$ niedawno opisanych modyfikacji grupy fosforanowej polega na prowadzeniu szkieletu składającego się z wiązania triazolowego (Rys. 5), co jak wykazano nie wpływa na replikację przez polimerazy zarówno w warunkach in vitro [67], jak i in vivo [68].

\subsection{MODYFIKACJE SZKIELETU NUKLEOZYDOWEGO}

Jedną z najbardziej udanych strategii naśladowania kwasów nukleinowych jest przeniesienie zasad nukleinowych na szkielet peptydowy w celu wytworzenia „peptydowych kwasów nukleinowych” (PNA). W związkach tego rodzaju szkielet cukrowo-fosforanowy jest zastąpiony obojętnym szkieletem na bazie poliamidu, przypominającym strukturę chemiczną występującą w białkach (Rys. 6). PNA są chemicznie proste, tworzą bardzo stabilne struktury dupleksu i tripleksu z oligonukleotydami PNA, DNA i RNA, a informacje przenoszone przez PNA można przenieść do innego PNA lub RNA. Niektóre z prekursorów PNA zostały znalezione metreorytach $i$ pracach eksperymentach prowadzonych w symulowanych warunkach prebiotycznych $[69,70]$.

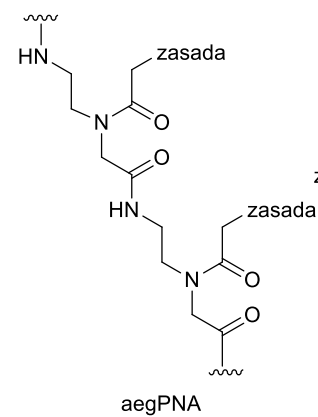

aegPNA

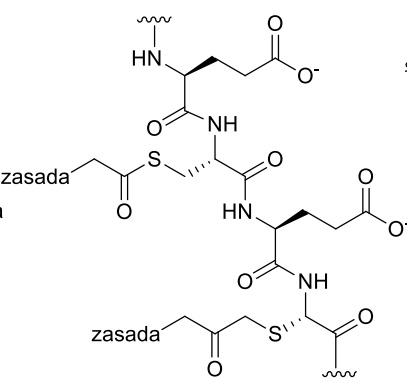

tPNA

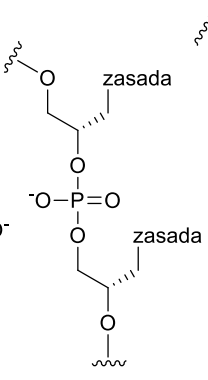

(S)-SNA

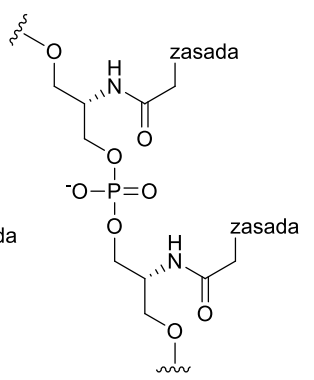

(S)-GNA

Rysunek 6. Kwasy ksenonukleinowe ze zmodyfikowanym szkieletem cukrowo-fosforanowym Figure 6. Xenonucleic acids with a modified sugar-phosphate backbone

W ciągu ostatnich kilku dekad zbadano wiele różnych wersji PNA, w tym analogi aminoetyloglicynowe (aegPNA) [71] i tioestrowe (tPNA) [71, 72] (Rys. 6). Najczęściej używanym PNA jest aegPNA ze względu na wysoką stabilnością termiczną i wysoką specyficzność parowania [73]. W przypadku tioestrowych 
analogów PNA zaobserwowano samoorganizowanie się nukleozasad na szkielecie peptydowym w obecności matrycy oligonukleotydowej [74]. Ten unikalny proces samoorganizacji może potencjalnie stać się podstawą mechanizmu replikacji w konstrukcie biologii syntetycznej.

Polimerami pokrewnymi peptydowym kwasom nukleinowym są glicerolowy kwas nukleinowy (GNA) i serynolowy kwas nukleinowy (SNA), w których rusztowanie cukrowo-fosforanowe jest zastąpione acyklicznymi szkieletami opartymi na glikolu propylenowym i serynolu (2-amino-1,3-propanodiolu) (Rys. 6). Związki te są naładowane ujemnie ze względu na obecność jednostek fosforanowych łączących monomery $\mathrm{i}$ - w przeciwieństwie do PNA - są chiralne. Wszystkie pochodne PNA, GNA, i SNA o zmodyfikowanych zasadach, reprezentują analogi DNA i RNA, w których wszystkie strukturalne części składowe zostały chemicznie zmienione $\mathrm{W}$ porównaniu $\mathrm{z}$ kanonicznymi nukleozydami [75-77].

\section{ROZSZERZANIE KODU GENETYCZNEGO}

Jednym z bardziej obiecujących podejść do projektowania komórek syntetycznych jest rozszerzenie kodu genetycznego, co pozwala na jego alternatywne odczytywanie. Przeprogramowanie biosyntezy białek za pomocą różnych ncAA może prowadzić do bezpiecznych szczepów drobnoustrojów o nowych funkcjach, będących jednocześnie tzw. „genetycznymi zaporami ogniowymi" [78].

Z rzadkimi wyjątkami, kod genetyczny wszystkich znanych organizmów koduje te same 20 aminokwasów [79, 80]. Sekwencja aminokwasów w polipeptydach jest określona przez sekwencję nukleotydów w mRNA. Cztery nukleotydy mogą tworzyć 64 trzyliterowe kodony i 61 z tych kodów koduje 20 cAA, a trzy pozostałe kodony, zwane kodonami terminacyjnymi, sygnalizuja zatrzymanie translacji. Zatem, aby wprowadzić nowe ncAA in vivo, należy uzyskać dodatkowe kodony lub przeprogramować już istniejące.

$\mathrm{Z}$ opracowanych dotychczas metod wprowadzania ncAA do białek najczęściej stosuje się dwa podejścia. W pierwszym wykorzystuje się auksotroficzny organizm ekspresyjny oraz zjawisko rozwiązłości naturalnej maszynerii translacji, polegające na tym, że niektóre transferowe RNA (tRNA) mogą przenosić ncAA strukturalnie podobne do ich pokrewnych kanonicznych aminokwasów. Odpowiedni ncAA dostarcza się egzogennie, a zaletą tej metodologii jest jej prostota technologiczna. Konieczne jest jednak dysponowanie odpowiednim auksotroficznym drobnoustrojem. Poza tym liczba ncAA, które można wprowadzić za pomocą tej technologii, jest ograniczona do bliskich analogów strukturalnych cAA. Co więcej, 
konsekwencją tego podejścia jest to, że możliwa jest tylko całkowita wymiana, często prowadząca do znacznej utraty aktywności i/lub stabilności białka [81].

Alternatywna metoda in vitro wykorzystuje jeden $\mathrm{z}$ trzech kodonów stop (UAG, UAA, UGA), który przeprogramowuje się na pożądany ncAA. Ponieważ kodon bursztynowy (UAG) jest najmniej używany u Escherichia coli (7-8\%), jest więc preferencyjnie wybierany do przekodowania. Gen kodujący badane białko $\mathrm{z}$ wprowadzoną nonsensowną (np. bursztynową) mutacją ulega translacji w tym układzie, co skutkuje włączeniem aminokwasu do rosnącego łańcucha polipeptydowego w określonym miejscu. Do thumienia kodonów stop wykorzystuje się ortogonalny system translacji, składający się $\mathrm{z}$ ortogonalnej syntetazy aminoacylo-tRNA $\mathrm{w}$ połączeniu $\mathrm{z}$ ortogonalnym tRNA, specjalnie zaprojektowanym dla danego ncAA. Jak dotąd za pomocą tej metody do białek włączono ponad 200 różnych ncAA [82].

Przykładem rozszerzenia kodu genetycznego przez zastąpienie aminokwasów w całym proteomie, było otrzymanie bakterii Escherichia coli zdolnych do wzrostu na syntetycznym niekanonicznym aminokwasie L- $\beta$-(tieno[3,2-b]pirolilo)alaninie $([3,2] \mathrm{Tpa})$ jako jedynym substytucie L-tryptofanu (Trp) (Rys. 7). Długoterminowe doświadczenie hodowlane na pożywkach syntetycznych pozwoliło otrzymać bakterie, w których 20899 kodonów UGG (kodujących Trp) zostało przeprogramowanych przez zastąpienie Trp-tRNATrp dostarczanym [3,2]TpatRNATrp, wytwarzanym przez tę samą syntetazę aminoacylo-tRNA. Bakterie te wykazywały silny wzrost przy całkowitym braku Trp [82]. Ewolucyjnie przystosowany szczep E. coli zastosowano później do ekspresji syntetyzowanego rybosomalnie i potranslacyjnie modyfikowanego peptydowego lantybiotyku lichenicydyny z resztą tryptofanu zastąpioną przez [3,2]Tpa o porównywalnej aktywności przeciwdrobnoustrojowej. Inżynieria lantybiotyków nie występujących w przyrodzie umożliwia dywersyfikację antybiotyków trudnych do zsyntetyzowania in vivo i odpowiada na niesłabnące zapotrzebowanie na nowe antybiotyki, które mogą ominąć naturalnie powstające mechanizmy obronne (super)patogenów $[84,85]$.

\section{KSENOENZYMY}

Inżynieria enzymów poczyniła $\mathrm{w}$ ostatnich dziesięcioleciach imponujące postępy torując drogę do powszechnego stosowania enzymów do różnych celów. Aktualnym kierunkiem, odmiennym od „klasycznej” inżynierii enzymów, która koncentruje się na optymalizacji specyficznych właściwości naturalnych biokatalizatorów, jest tworzenie sztucznych enzymów, które katalizują reakcje nieobserwowane w naturze. Większość opisanych do tej pory sztucznych enzymów 
nie wykazuje wysokiej aktywności in vivo, jednak mogą one nadawać komórkom zupełnie nowe funkcje [86]. Obserwowany obecnie trend tworzenia sztucznych enzymów, różniących się od naturalnych odpowiedników sekwencją aminokwasów, stosowanymi kofaktorami lub katalizowaną reakcją nazwano „czwartą falą biokatalizy" [87].

Nowe katalizatory tworzy się poprzez zmianę przeznaczenia naturalnych enzymów (wykorzystując katalityczną rozwiązłość niektórych enzymów), wprowadzenie nienaturalnych, aktywnych katalitycznie ugrupowań do białek lub obliczeniowe projektowanie enzymu w kierunku pożądanej reakcji. Przykładem podejścia drugiego typu jest zastosowanie niekanonicznych aminokwasów do kotwiczenia jonów metali, kofaktorów, poprawy właściwości, takich jak aktywność, selektywność i stabilność, a także do umożliwienia katalizowania nowych transformacji. 20 standardowych aminokwasów oferuje wąski zestaw grup funkcyjnych, co ogranicza zdolności katalityczne enzymów. Na przykład żaden aminokwas kanoniczny nie może działać jako silny elektrofil. Problem ten został przez naturę rozwiązany poprzez użycie metali i innych kofaktorów, a także poprzez modyfikację posttranslacyjną. Metodą inżynierii białek można precyzyjnie wprowadzić niekanoniczne aminokwasy uzyskując pożądaną nienaturalną funkcjonalność [88].

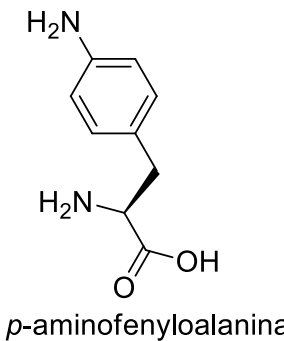

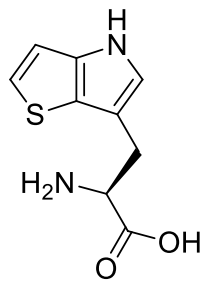

$[3,2] \mathrm{Tp}$

Rysunek 7. Wybrane niekanoniczne aminokwasy

Figure 7. Selected non-canonical amino acids

Jednym z nielicznych przykładów zastosowania niekanonicznego aminokwasu bezpośrednio do katalizy jest wprowadzenie $p$-aminofenyloalaniny (Rys. 7) do wielolekowego represora transkrypcyjnego Lactococcus lactis (LmrR). Służy ona jako katalizator nukleofilowy w reakcji tworzenia hydrazonu (Rys. 8) [89]. Dzięki wykorzystaniu ukierunkowanej ewolucji poprawiono szybkości katalityczną enzymu zwiększając stukrotnie wartość stałej katalitycznej $\mathrm{k}_{\text {cat }}$ [90]. 


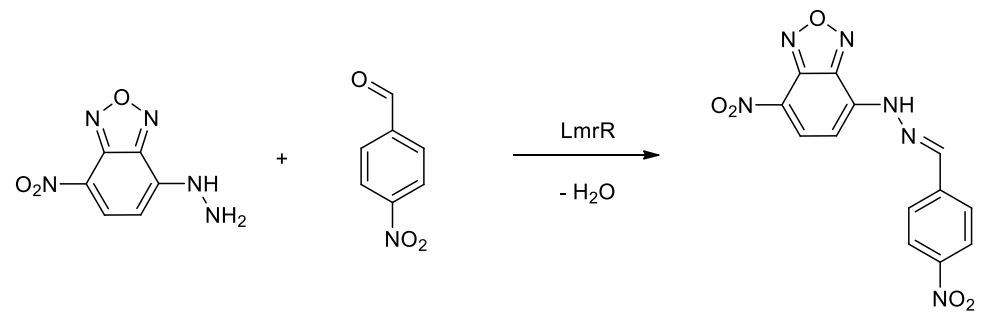

Rysunek 8. Tworzenie hydrazonu przez wielolekowy represor transkrypcyjny Lactococcus lactis LmrR niekanonicznym aminokwasem $\quad \mathrm{z}$ użyciem 4-hydrazyno-7-nitro-2,1,3-benzoksadiazolu i 4-nitrobenzaldehydu [89]

Figure 8. Non-canonical aminoacid catalyzed hydrazone formation by the Lactococcus lactis multidrug transcriptional regulator LmrR using 4-hydrazino-7-nitro-2,1,3-benzoxadiazole and 4-nitrobenzaldehyde [89]

Pomimo wielu interakcji, które muszą być brane pod uwagę przy obliczeniowym projektowaniu skutecznego katalizatora, do tej pory opisano szereg enzymów zaprojektowanych pod kątem wybranej funkcji [90]. Wytwarzanie sztucznych enzymów, które są aktywne katalitycznie in vitro i funkcjonalne biologicznie in vivo jest kluczowym celem chemicznej biologii syntetycznej. Jedynie kilka w pełni biokompatybilnych sztucznych enzymów było w stanie przejąć funkcje komórkowe, jak na przykład sztuczna esteraza enterobaktyny żelazowej, której ekspresja w szczepie $E$. coli z delecją naturalnej esterazy, pozwala bakteriom rosnąć w pożywce $\mathrm{z}$ ograniczoną zawartością żelaza [92]. Badania te pokazują, że sztuczne enzymy mogą zastąpić ich naturalne odpowiedniki in vivo, jednak poszerzenie zakresu funkcji komórkowych i stworzenie organizmów opierających się na chemii bioortogonalnej wymaga osiągnięcia tego samego dla reakcji nieobserwowanych $\mathrm{w}$ naturze. Takie abiotyczne transformacje może katalizować zaprojektowana de novo peroksydaza hemowa, wykazująca również zdolność do efektywnego i stereoselektywnego międzycząsteczkowego transferu karbenów do olefin, heterocykli, aldehydów i amin. Opisana dla tego enzymu reakcja rozbudowania pierścienia prostej cyklicznej cząsteczki pirolu w celu utworzenia prekursora $\mathrm{NAD}^{+}$, ważnego biologicznego kofaktora, prowadzona w beztlenowych hodowlach E. coli, ma potencjał aplikacyjny [93] (Rys. 9).

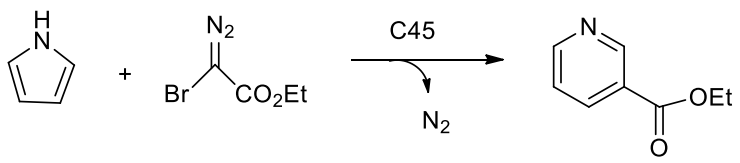

Rysunek 9. Rozbudowanie pierścienia heteroaromatycznego pirolu do nikotynianu etylu z użyciem 2-bromo-2-diazooctanu etylu katalizowane przez syntetyczną peroksydazę hemową C45 [93]

Figure 9. Heteroaromatic pyrrole ring expansion to ethyl nicotinate using ethyl-2-bromo-2-diazoacetate catalyzed by synthetic heme peroxidase $\mathrm{C} 45$ [93] 
Obecnie integracja sztucznych enzymów z metabolizmem żywych komórek pozostaje w dużej mierze niezbadanym terenem, jednak można przewidywać, że biologia syntetyczna odniesie duże korzyści z ksenoenzymów, ponieważ umożliwią one opracowanie nowych szlaków i otrzymywanie nowych dla natury związków zrównoważonymi drogami.

\section{KOMÓRKA MINIMALNA}

Jedną z bardziej ambitnych aspiracji współczesnej biologii jest synteza sztucznych żywych komórek, tworząc tym samym nieograniczone możliwości badawcze. Aby zmniejszyć poziom trudności tego zadania, większość wysiłków koncentruje się na syntezie komórki minimalnej. Ze względu na odmienny skład chemiczny materiału genetycznego, komórki takie nie mogą wymieniać żadnych informacji genetycznych z organizmami naturalnymi. Podobną izolację można również osiągnąć poprzez zmianę kodu genetycznego i przypisanie translacji trypletów kodonów na inne aminokwasy. W obu przypadkach powstałe organizmy nie mogą oddziaływać genetycznie ze środowiskiem i dlatego nazywane są ortogonalnymi. Co ważne, ortogonalność syntetycznych komórek zapewnia wysoki poziom bezpieczeństwa biologicznego [94].

Koncepcja komórki minimalnej ma istotne znaczenie przy określaniu minimalnych i jednocześnie wystarczających warunków życia komórkowego, a także przy poznawaniu wczesnych komórek, które były prawdopodobnie znacznie prostsze niż komórki współczesne [95, 96]. Poza wspomnianymi aspektami, badania na komórkach minimalnych mogą być przydatne przy opracowywaniu prostych reaktorów komórkowych do różnych zastosowań [97] oraz mogą przynieść znaczne rozszerzenie różnorodności form życia.

Podejście odgórne tworzenia komórki minimalnej polega na dekonstrukcji żywych komórek, natomiast oddolne na składaniu nieożywionych składników biologicznych, tj. samoreplikującego się kwasu nukleinowego, mechanizmu metabolicznego i struktury kapsułkującej, w celu uzyskania układu, który można by uznać za żywy. Chociaż żaden układ oddolny nie został jeszcze pomyślnie skonstruowany, jednak poczyniono już w tym względzie postępy w postaci projektowania bardziej wyrafinowanych przedziałów przypominających komórki [98].

\subsection{MINIMALNY GENOM}

Minimalizacja genomu to odgórne podejście biologii syntetycznej mające na celu złożenie sztucznego genomu zawierającego tylko te geny, które są absolutnie niezbędne do życia i wzrostu. Najmniejszy genom ze wszystkich wolno żyjących 
organizmów posiadają bakterie Mycoplasma mycoides JCVI-syn3.0, wyprodukowane $\mathrm{w}$ wyniku redukcji informacji genetycznej szczepu JCVI-syn 1.0 (pierwszego organizmu z całkowicie syntetycznym genomem) z 901 do 473 genów [99, 100]. Bakterię Mycoplasma mycoides JCVI-syn3.0 uznaje się za pierwszą syntetyczną minimalną komórkę.

Ostatnie badania prowadzone na zminimalizowanych genomowo komórkach bakterii Mycoplasma mycoides JCVI-syn3A pokazują, że do prawidłowego podziału komórki wymagane jest łącznie siedem genów, do których należą dwa znane geny podziału komórki ( ftsZ i sepF), hydrolaza o nieznanym podłożu oraz cztery geny kodujące białka związane z błoną o nieznanej funkcji [101]. Wnioski takie wyciągnięto obserwując odzyskanie prawidłowego podziału i morfologii w komórkach, którym przywrócono 19 genów usuniętych przy tworzeniu JCVIsyn3.0 z JCVI-syn1.0, co skutkowało nieregularnym podziałem komórek i pleomorfizmem. Rola tych wcześniej niescharakteryzowanych genów, jak również poligeniczna podstawa normalnego podziału i morfologii komórki, mogą być użyteczne przy oddolnym podejściu odtwarzania podziału komórek w komórkach syntetycznych. Dla zminimalizowanych genomowo komórek bakterii JCVI-syn3A opracowano pierwszy obliczeniowy model metaboliczny, łącząc sekwencje DNA z procesami molekularnymi na poziomie całego systemu biologicznego [102].

\subsection{SYNTETYCZNE BLOKI BUDULCOWE}

Szybki postęp obserwowany w badaniach nad oddolnym konstruowaniem syntetycznych komórek sugeruje, że integracja syntetycznych bloków budulcowych w funkcjonalną syntetyczną komórkę może być osiągalna w niedalekiej przyszłości. Opracowano już wiele systemów supramolekularnych w celu odtworzenia funkcji komórkowych, takich jak podział na kompartmenty [103, 104], replikacja DNA [105, 106], metabolizm [107, 108], mobilność i kształt [109, 110] oraz komunikacja [111]. Do najnowszych osiągnięć $\mathrm{w}$ zakresie inspirowanego naturą samoorganizowania się należą przykłady układów supramolekularnych przedstawione poniżej.

Procesy życiowe zachodzą $w$ zamkniętych mikrośrodowiskach tj. w komórkach i organellach. Komunikacja i adaptacja podobna do komórkowej projektowana jest pomiędzy wieloma supramolekularnymi przedziałami. Efektem badań z tego zakresu są fagocytarne dendrymerosomy zdolne do endocytozy żywych bakterii poprzez niekowalencyjną adhezję błonową, będącej efektem wysokiej elastyczności i stabilności polimerowych pęcherzyków [112].

Przykładem syntetycznego wzmocnienia ruchu, który jest jedną z podstawowych cech organizmów żywych, może być urządzenie ruchowe przypominające komórkę. Supramolekularne pęcherzyki polimerowe o wklęsłym 
kształcie, zwane stomatocytami, załadowane są nanocząstkami platyny, katalizującymi produkcję napędzającego ruch tlenu z nadtlenku wodoru. Prędkość i kierunek ruchu mogą być regulowane temperaturą poprzez odwracalne otwieranie i zamykanie centrum katalitycznego za pomocą termoreaktywnych polimerów [113].

Specyficzne wiązanie ligand-receptor jest podstawą rozpoznania i komunikacji komórkowej. Ponieważ węglowodany często odpowiadają za bezpośrednie interakcjach komórka-komórka, wiele badań dotyczy opracowania syntetycznych receptorów glikanowych o wysokiej specyficzności. Do selektywnego wiązania glukozy opracowano syntetyczny biomimetyczny receptor o kieszeni idealnie dopasowanej do całkowicie ekwatorialnego $\beta$-piranozydu [114]. Powinowactwo receptora tego do glukozy w środowisku wodnym jest porównywalne z naturalnymi systemami receptorowymi, dzięki zaprojektowanym oddziaływaniom hydrofobowym i hydrofilowym.

\section{UWAGI KOŃCOWE}

Chemiczna biologia syntetyczna wyłoniła się z ambitnych celów, jakimi są zrozumienie fundamentalnych mechanizmów życia i jego pochodzenia oraz dążenie do naśladowania go poprzez odwrotną inżynierię. Badania podstawowe nad chemicznie modyfikowanymi kwasami nukleinowymi dostarczyły istotnych informacji na temat stabilności różnych form DNA i RNA, a także pozwoliły na głębsze zrozumienie zależności struktura-funkcja. $Z$ kolei rozszerzenie kodu genetycznego i zdolność do genetycznego włączania niekanonicznych aminokwasów do białek dostarczyła użytecznych narzędzi do badania i manipulowania strukturą i funkcją tych polimerów. Zgodnie z założeniami chemicznej biologii syntetycznej, badania nad otrzymaniem komórki minimalnej przyczyniły się do znacznego postępu w zrozumieniu wielu mechanizmów biologicznych. Biologom udało się już stworzyć minimalną syntetyczną komórkę bakteryjną, zawierającą mniej genów niż jakikolwiek znany żywy organizm, która może rosnąć samodzielnie [98], jednak cel, jakim jest minimalna komórka zaprojektowana i stworzona oddolnie z otrzymanych chemicznie bloków budulcowych, jest nadal niezrealizowany.

\section{PODZIĘKOWANIA}

Niniejszą pracę dedykuję mojemu mentorowi - Panu Profesorowi Bogdanowi Burczykowi. 


\section{PIŚMIENNICTWO CYTOWANE}

[1] S.A. Benner, Z. Yang, F. Chen, C.R .Chim., 2011, 14, 372.

[2] Nat. Biotechnol., 2009, 27, 1071.

[3] D. Endy, Nature, 2005, 438, 449.

[4] A. Arkin, Nat. Biotechnol., 2008, 26,771.

[5] M. Elowitz, S. Leibler, Nature, 2000, 403, 335.

[6] T.S. Gardner, C.R. Cantor, J.J. Collins, Nature, 2000, 403, 339.

[7] R. Kwok, Nature, 2010, 463, 288.

[8] A.A.K. Nielsen, B.S. Der, J. Shin, P. Vaidyanathan, V. Paralanov, E.A. Strychalski, D. Ross, D. Densmore, C.A. Voigt, Science, 2016, 352, aac7341.

[9] F.H. Arnold, Angew. Chem., 2018, 57, 4143.

[10] J. Doudna, E. Charpentier, Science, 2014, 346, 6213.

[11] F. Meng, T. Ellis, Nat. Commun., 2020, 11, 5174.

[12] C.A. Voigt, Nat. Commun., 2020, 11, 6379.

[13] P. Calero, P.I. Nikel, Microb. Biotechnol., 2019, 12, 98.

[14] K. Campbell, J. Xia, J. Nielsen, Trends. Biotechnol., 2017, 35, 1156.

[15] W. Sabra, C. Groeger, A.P. Zeng, Adv. Biochem. Eng. Biotechnol., 2016, 155, 165.

[16] T. Tiso, N. Wierckx, L.M. Blank, Industrial Biocatalysis, Boca Raton, FL: CRC Press, New York, 2014.

[17] S.H. Kung, S. Lund, M. Abhishek, D. McPhee, C.J. Paddon, Front. Plant Sci., 2018, 9, 87.

[18] A. Casini, F.Y. Chang, R. Eluere, A.M. King, E.M. Young, Q.M. Dudley, A. Karim, K. Pratt, C. Bristol, A. Forget, A. Ghodasara, R. Warden-Rothman, R. Gan, A. Cristofaro, A.E. Borujeni, M.H. Ryu, J. Li, Y.C. Kwon, H. Wang, E. Tatsis, C. Rodriguez-Lopez, S. O’Connor, M.H. Medema, M.A. Fischbach, M.C. Jewett, C. Voigt, D.B. Gordon, J. Am. Chem. Soc., 2018, 140, 4302 .

[19] S.A. Benner, F. Chen, Z.Y. Yang, Chemical Synthetic Biology, Wiley, Chichester, 2011.

[20] M. Schmidt, Synthetic biology. The Technoscience and Its Societal Consequences, Springer, Berlin, 2010.

[21] M. Good, X. Trepat, Nature, 2018, 563, 188.

[22] P.L. Luisi, Chem. Biodivers., 2007, 4, 603.

[23] M. Schmidt, Bioessays, 2010, 32, 322.

[24] T. Carell, C. Brandmayr, A. Hienzsch, M. Müller, D. Pearson, V. Reiter, I. Thoma, P. Thumbs, M. Wagner, Angew. Chem., 2012, 51, 7110.

[25] D.A. Malyshev, K. Dhami, T. Lavergne, T. Chen, N. Dai, J. M. Foster, I. R. Correa Jr, F.E. Romesberg, Nature, 2014, 509, 385.

[26] D.H. Appella, Curr. Opin. Chem. Biol., 2009, 13, 687.

[27] W. Saenger, Principles of Nucleic Acid Chemistry, Springer, New York, 1984.

[28] N. Martin-Pintado, M. Yahyaee-Anzahaee, R. Campos-Olivas, A.M. Noronha, C.J. Wilds, M.J. Damha, C. Gonzalez, Nucleic Acids Res., 2012, 40, 9329.

[29] A. Matsugami, T. Ohyama, M. Inada, N. Inoue, N. Minakawa, A. Matsuda, M. Katahira, Nucleic Acids Res., 2008, 36, 1805.

[30] A. Eschenmoser, Science, 1999, 284, 2118.

[31] I. Anosova, E.A. Kowal, M.R. Dunn, J.C. Chaput, W.D. Van Horn, M. Egli, Nucleic Acids Res. 2016, 44, 1007.

[32] K.-U. Schçning, P. Scholz, S. Guntha, X. Wu, R. Krishnamurthy, A. Eschenmoser, Science, 2000, 290, 1347.

[33] A. Hendrix, H. Rosemeyer, I. Verheggen, A. Van Aerschot, F. Seela, P. Herdewijn, Chem. Eur. J., 1997, 3, 110. 
[34] L.N. Jackson, N. Chim, C. Shi, J.C. Chaput, Nucleic Acids Res., 2019, 47, 6973.

[35] M.-O. Ebert, C. Mang, R. Krishnamurthy, A. Eschenmoser, B. Jaun, J. Am. Chem. Soc., 2008, 130, 15105.

[36] R. Krishnamurthy, S. Pitsch, M. Minton, C. Miculka, N. Windhab, A. Eschenmoser, Angew. Chem. Int. Ed. 1996, 35, 1537.

[37] A. Taylor, V. Pinheiro, M. Smola, A.S. Morgunov, S. Peak-Chew, C. Cozens, K.M. Weeks, P. Herdewijn, P. Holliger, Nature, 2015, 518, 427.

[38] C.A. Mattelaer, M. Maiti, L. Smets, M. Maiti, G. Schepers, H.P. Mattelaer, H. Rosemeyer, P. Herdewijn, E. Lescrinier, Chembiochem. 2021, 22, 1638.

[39] T. Carell, C. Brandmayr, A. Hienzsch, M. Muller, D. Pearson, V. Reiter, I. Thoma, P. Thumbs, M. Wagner, Angew. Chem., 2012, 51, 7110.

[40] M. Hocek, Acc. Chem. Res., 2019, 52, 1730.

[41] B.T. Le, M. Hornum, P.K. Sharma, P. Nielsen, R.N. Veedu, RSC Adv., 2017, 7, 54542.

[42] H. Peacock, A. Kannan, P. A. Beal, C. J. Burrows, J. Org. Chem., 2011, 76, 7295.

[43] M. Kimoto, I. Hirao, ACS Synth. Biol., 2017, 6, 1944.

[44] A.F. Fuchtbauer, M.S. Wranne, M. Bood, E. Weis, P. Pfeiffer, J.R. Nilsson, A. Dahlen, M. Grotli, L.M. Wilhelmsson, Nucleic Acids Res., 2019, 47, 9990.

[45] A. Simonova, I. Magrina, V. Sykorova, R. Pohl, M. Ortiz, L. Havran, M. Fojta, C.K. O’Sullivan and M. Hocek, Chem. - Eur. J., 2020, 26, 1286.

[46] Z.H. Qiu, L.H. Lu, X. Jian and C. He, J. Am. Chem. Soc., 2008, 130, 14398.

[47] Z. Vanikova, M. Janouskova, M. Kambova, L. Krasny, M. Hocek, Chem. Sci., 2019, 10, 3937.

[48] D.A. Malyshev, F.E. Romesberg, Angew. Chem., 2015, 54, 11930.

[49] L.Q. Zhang, Z.Y. Yang, K. Sefah, K.M. Bradley, S. Hoshika, M.J. Kim, H.J. Kim, G.Z. Zhu, E. Jimenez, S. Cansiz, I.T. Teng, C. Champanhac, C. McLendon, C. Liu,W. Zhang, D.L. Gerloff, Z. Huang, W.H. Tan, S.A. Benner, J. Am. Chem. Soc., 2015, 137, 6734.

[50] Z. Yang, A.M. Sismour, P. Sheng, N.L. Puskar, S.A. Benner. Nucleic Acids Res., 2007, 35, 4238.

[51] Z. Yang, A.M. Sismour, S.A. Benner, Nucleic Acids Res., 2007, 35, 3118.

[52] J.C. Delaney, J. Gao, H. Liu, N. Shrivastav, J.M. Essigmann, E.T. Kool, Angew. Chem., 2009, 48, 4524.

[53] M. Kimoto, R. Kawai, T. Mitsui, S. Yokoyama, I. Hirao. Nucleic Acids Res. 2009; 37:e14.

[54] Y.J. Seo, G.T. Hwang, P. Ordoukhanian, F.E. Romesberg, J. Am. Chem. Soc., 2009, 131, 3246.

[55] Y.J. Seo, S. Matsuda, F.E. Romesberg, J. Am. Chem. Soc., 2009, 131, 5046.

[56] I. Ivancova, R. Pohl, M. Hubalek, M. Hocek, Angew. Chem., 2019, 58, 13345.

[57] J. Micklefield, Curr. Med. Chem., 2001, 8, 1157.

[58] K.H. Jung, A. Marx, Cell. Mol. Life Sci., 2005, 62, 2080.

[59] F. Eckstein, Nucl. Acid Ther., 2014, 24, 374.

[60] N. Iwamoto, D.C.D. Butler, N. Svrzikapa, S. Mohapatra, I. Zlatev, D.W. Y. Sah, Meena, S.M. Standley, G.L. Lu, L.H. Apponi, M. Frank-Kamenetsky, J.J. Zhang, C. Vargeese, G.L. Verdine, Nat. Biotechnol., 2017, 35, 845.

[61] M.A. Islam, A. Fujisaka, J. Kawakami, T. Yamaguchi, S. Obika, Bioorg. Med. Chem. Lett., 2020, 30, 4 .

[62] T. Ueda, H. Tohda, N. Chikazumi, F. Eckstein, K. Watanabe, Nucleic Acids Res., 1991, 19, 547.

[63] L. Wang, S. Chen, T. Xu, K. Taghizadeh, J.S. Wishnok, X. Zhou, D. You, Z. Deng, P.C. Dedon, Nat. Chem. Biol., 2007, 3, 709.

[64] B.R. Shaw, M. Dobrikov, X. Wang, J. Wan, K. He, J. L. Lin, P. Li, V. Rait, Z.A. Sergueeva, D. Sergueev, Ann. N. Y. Acad. Sci., 2003, 1002, 12. 
[65] M. Renders, G. Emmerechts, J. Rozenski, M. Krecmerova, A. Holy, P. Herdewijn, Angew. Chem., 2007, 46, 2501.

[66] A. Loakes, P. Holliger, Chem Commun (Camb), 2009, 31, 4619.

[67] J.F. Chen, Y.R. Baker, A. Brown, A.H. El-Sagheer, T. Brown, Chem. Sci., 2018, 9, 8110.

[68] L. Taemaitree, A. Shivalingam, A.H. El-Sagheer, T. Brown,Nat. Commun., 2019, 10, 1610.

[69] S.L. Miller, J.P. Dworkin, A. Lazcano, J. Theor. Biol., 2003, 222, 127.

[70] E.K. Nelson, M. Levy, S.L. Miller, PNAS, 2000, 97, 3868.

[71] P.E. Nielsen, M. Egholm, R.H. Berg, O. Buchardt, Science, 1991, 254, 1497.

[72] Y. Ura, J.M. Beierle, L.J. Leman, L.E. Orgel, M.R. Ghadiri, Science, 2009, 325, 73.

[73] M. Egholm, O. Buchardt, L. Christensen, C. Behrens, S.M. Freier, D.A. Driver, R.H. Berg, S.K. Kim, B. Norden, P.E. Nielsen, Nature, 1993, 365, 566.

[74] Y. Ura, J.M. Beierle, L.J. Leman, L.E. Orgel, M.R. Ghadiri, Science, 2009, 325, 73.

[75] M. Suchy, R.H.E. Hudson, J. Org. Chem., 2014, 79, 3336.

[76] B. Jash, J. Mueller, Angew. Chem., 2018, 57, 9524.

[77] K. Murayama, Y. Yamano, H. Asanuma, J. Am. Chem. Soc., 2019, 141, 9485.

[78] N. Budisa, Curr. Org. Chem., 2014, 18, 936.

[79] G. Srinivasan, C.M. James, J.A. Krzycki, Science, 2002, 296, 1459.

[80] A. Böck, K. Forchhammer, J. Heider, W. Leinfelder, G. Sawers, B. Veprek, F. Zinoni, Mol. Microbiol., 1991, 5, 515.

[81] M.J. Schmidt, D. Summerer, Front. Chem., 2014, $2,7$.

[82] O. Vargas-Rodriguez, A. Sevostyanova, D. Söll, A. Crnković, Curr. Opin. Chem. Biol. 2018, 46, 115.

[83] M.G. Hoesl, S. Oehm, P. Durkin, E. Darmon, L. Peil, H.R. Aern, J. Rappsilber, J. Rinehart, D. Leach, D. Söll, N. Budisa, Angew. Chem., 2015, 54, 10030.

[84] A. Kuthning, P. Durkin, S. Oehm, M.G. Hoesl, N. Budisa, R.D. Süssmuth, Sci. Rep., 2016, 6, 33447 .

[85] H.R. Karbalaei-Heidari, N. Budisa, Front. Microbiol., 2020, 11, 590522.

[86] T. Vornholt, M. Jeschek, ChemBioChem. 2020, 21, 2241-2249.

[87] U.T. Bornscheuer, Philos. Trans. R. Soc. London, 2018, 376, 20170063.

[88] C.C. Liu, P.G. Schultz, Annu. Rev. Biochem., 2010, 79, 413.

[89] I. Drienovská, C. Mayer, C. Dulson, G. Roelfes, Nat. Chem., 2018, 10, 946.

[90] A. Mayer, C. Dulson, E. Reddem, A.M.W.H. Thunnissen, G. Roelfes, Angew. Chem., 2019, 58, 2083.

[91] V. Vaissier Welborn, T. Head-Gordon, Chem. Rev., 2019, 119, 6613.

[92] A.E. Donnelly, G.S. Murphy, K.M. Digianantonio, M.H. Hecht, Nat. Chem. Biol. 2018, 14, 253.

[93] R. Stenner, J.W. Steventon, A. Seddon, J.L.R. Anderson, Proc. Natl. Acad. Sci. USA 2020, 117, 141.

[94] D.J. Mandell, M.J. Lajoie, M.T. Mee, R. Takeuchi, G. Kuznetsov, J.E. Norville, C.J. Gregg, B.L. Stoddard, G.M. Church, Nature, 2015, 518, 55.

[95] J.W. Szostak, D.P. Bartel, P.L. Luisi, Nature, 2001, 409, 387.

[96] C. Forster, G.M. Church, Mol. Syst. Biol. 2006, 2, 45.

[97] V. Noireaux, A.P. Liu, Annu. Rev. Biomed. Eng. 2020, 22, 51.

[98] M. Exterkate, A.J.M. Driessen, ACS Omega, 2019, 4, 5293.

[99] C.A. Hutchison, R.Y. Chuang, V.N. Noskov, N. Assad-Garcia, T.J. Deerinck, M.H. Ellisman, J. Gill, K. Kannan, B.J. Karas, L. Ma, J.F. Pelletier, Z.Q. Qi, R.A. Richter, E.A Strychalski, L. Sun, Y. Suzuki, B. Tsvetanova, K.S. Wise, H.O. Smith, J.I. Glass, C. Merryman, D.G. Gibson, J.C. Venter, Science, 2016, 351:aad6253.

[100] D.G. Gibson, J.I. Glass, C. Lartigue, V.N. Noskov, R.-Y. Chuang, M.A. Algire, G.A. Benders, M.G. Montague, L. Ma, M.M. Moodie, C. Merryman, S. Vashee, R. Krishnakumar, N. Assad- 
Garcia, C. Andrews-Pfannkoch, E.A. Denisova, L. Young, Z.-Q. Qi, T.H. Segall-Shapiro, C.H.

Calvey, P.P. Parmar, C.A. Hutchison, H.O. Smith, J.C. Venter, Science, 2010, 329, 52-56.

[101] J.F. Pelletier, L. Sun, K.S. Wise, N. Assad-Garcia, B.J. Karas, T.J. Deerinck, M.H. Ellisman, A. Mershin, N. Gershenfeld, R.-Y. Chuang, J.I. Glass, E.A. Strychalski, Cell, 2021, 184, 2430.

[102] M. Breuer, T.M. Earnest, C. Merryman, K.S. Wise, L. Sun, M.R. Lynott, C.A. Hutchison, H.O. Smith, J.D. Lapek, D.J. Gonzalez, V. de Crécy-Lagard, D. Haas, A.D. Hanson, P. Labhsetwar, J.I. Glass, Z. Luthey-Schulten, eLife, 2019, 8, e36842.

[103] L. Aufinger, F.C. Simmel, Angew. Chem., 2018, 57, 17245.

[104] K. Vogele, T. Frank, L. Gasser, M.A. Goetzfried, M.W. Hackl, S.A. Sieber, F.C. Simmel, T. Pirzer, Nat. Commun., 2018, 9, 3862.

[105] K. Libicher, R. Hornberger, M. Heymann, H. Mutschler, Nat. Commun., 2020, 11, 904.

[106] M. Suetsugu, H. Takada, T. Katayama, H. Tsujimoto, Nucleic Acids Res., 2017, 45, 11525.

[107] T.E. Miller, T. Beneyton, T. Schwander, C. Diehl, M. Girault, R. McLean, T. Chotel, P. Claus, N.S. Cortina, J.C. Baret, Science, 2020, 368, 649.

[108] S. Berhanu, T. Ueda, Y. Kuruma, Nat. Commun., 2019, 10, 1325.

[109] C. Fanalista, A. Birnie, R. Maan, F. Burla, K. Charles, G. Pawlik, S. Deshpande, G.H. Koenderink, M. Dogterom, C. Dekker, ACS Nano, 2019, 13, 5439.

[110] X. Cheng, J.E. Ferrell, Science, 2019, 366, 631.

[111] H. Niederholtmeyer, C. Chaggan, N.K. Devaraj, Nat. Commun., 2018, 9, 1.

[112] N.Y. Kostina, K. Rahimi, Q. Xiao, T. Haraszti, S. Dedisch, J.P. Spatz, U. Schwaneberg, M.L. Klein, V. Percec, M. Möller, C. Rodriguez-Emmenegger, Nano Lett., 2019, 19, 5732.

[113] Y. Tu, F. Peng, X. Sui, Y. Men, P.B. White, J.C. M Hest,. D.A. Wilson, Nat. Chem. 2017, 9, 480.

[114] R.A. Tromans, T.S. Carter, L. Chabanne, M.P. Crump, H. Li, J.V. Matlock, M.G. Orchard, A.P. Davis, Nature Chem., 2019, 11, 52.

Praca wpłynęła do Redakcji 10 czerwca 2021 r. 